\title{
TroyAcademy
}

International Journal of Social Sciences

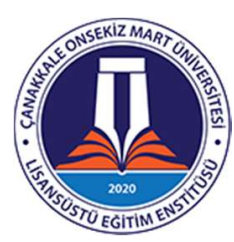

\section{Türk Basınında 1921 Maarif Kongresi}

\author{
Araştırma Makalesi/Research Article
}

\section{Harun KARAKÜTÜK*}

\section{ÖZET}

Basın-yayın araçları kullanılmaya başlandıkları zaman diliminden beri toplumların kendini ifade etmesinde etkin rol üstlenmiştir. Toplumu oluşturan bireylerin herhangi bir olay karşısındaki tutumları, duygu ve düşünceleri basın-yayın araçları sayesinde ortaya çıkma imkânı bulmuştur. Ele aldığımız bu çalışmanın temel amacı da yüz yıl öncesinde, Birinci Dünya Savaşı ve ardından başlayan Millî Mücadele yıllarında, Türk halkının cephede düşmana karşı silahlı mücadele verirken diğer taraftan ülke içerisinde cehalete karşı verdiği mücadeleyi, dönemin basın-yayın araçlarında yer alan haberler doğrultusunda ortaya koymaktır. Gazeteler, Kongre boyunca konuya yoğun ilgi göstermiştir. Birçok gazete Kongre hakkında köşe yazıları ve makaleler yayınlamıştır. Kongre'nin toplanması gazeteler tarafindan askeri cepheden ayrı ikinci bir cephe olarak nitelendirilmiştir. Yapılan haberler ile savaş zamanında bir eğitim kongresinin toplanmış olması cephedeki savaşın yakın zamanda zaferle neticeleneceğinin bir habercisi olarak kabul edilmiştir.

Anahtar Kelimeler: Basın, Gazete, Köşse Yazısı, Maarif.

\section{Education Congress In The Turkish Press}

\section{ABSTRACT}

Media has played an active role in the self-expression of societies since the time they started to be used. The attitudes, feelings and thoughts of the individuals who make up the society have the opportunity to emerge due to the media. The main aim of this study is to reveal the struggle of the Turkish people against ignorance in the country while fighting armed enemy on the front, in the years of the First World War and Turkish National War of Independence that began after a hundred years ago, in accordance with the news contained in the press and publishing tools of the period. Newspapers have shown intense interest in the issue throughout the Congress. Many newspapers have published columns and articles about the Congress. Assembling of the Congress was characterized by newspapers as a second front separate from the military front. In published news it is accepted that an education congress in war time means the war at the front will result with victory.

Keywords: Press, Newspaper, Corner Post, Education.

* Tarih Öğretmeni, Kartal Mesleki Eğitim Merkezi, Millî Eğitim Bakanlığı, harun_karakutuk@hotmail.com, ORCID ID: https://orcid.org/0000-0003-2503-4306 


\section{GíRIŞ}

Eğitim, bireyin yaşantı yoluyla davranışlarında değişiklik meydana getirme sürecidir. Bu süreç kişinin hayatı boyunca devam eder. Türkler tarihleri boyunca küçük yaşlardan başlayarak toplumsal eğitime yönelik çalışmalarda bulunmuştur. İslamiyet öncesi Türk toplumlarının eğitim biçimini doğup büyüdükleri bozkırın zorlu koşulları belirlemiştir. Bozkır hayatının sürekli olarak tehlikelere açık olması, toplumun boy teşkilatı halinde örgütlenmesi; eğitim anlayışında savaş teknikleri ve yöneticilik becerilerini kazandırmaya dönük çalışmaların ön planda tutulmasına neden olmuştur (Rencüzoğlu, 2017: 426). İslamiyet'in kabulünden sonra ise eğitim anlayışı zamanla medrese etrafında gelişim göstermiştir. Osmanlı Devleti’nin son dönemlerindeki batılılaşma faaliyetleri kapsamında eğitim anlayışı da batılı anlamda modernize edilmeye çalışılmıştır. Bu yıllarda üst üste uzun ve yıpratıcı savaşların yaşanması modernize çalışmalarının başarıya ulaşmasını engellemiştir. Öyle ki yeni Türk devleti kurulduğunda çağın gereksinimlerinden uzak bir eğitim sistemi miras almıştır (Kılavuz ve Tanık, 2011: 354).

1921 Maarif Kongresi'ni incelediğimiz bu çalışmaya esas oluşturan başlıca kaynaklar dönemin basın hayatının en aktif araçları olan gazetelerdir. Bu kaynaklarda bulunan bilgiler dönemin yoğun siyasi ve askeri iklimi içerisinde eğitime verilen değerin günümüz şartlarında daha net anlaşılmasına yardımcı olacaktır. Araştırma boyunca elde edilen bu (Arap harfli) belgeler, öncelikle günümüzde Türk dilini ifade etmek için kullanılan (Latin) harflere aktarılmıştır. Bu yoldan ulaşılan bilgiler tarihsel metotlar doğrultusunda analiz, sentez ve değerlendirme aşamalarından geçirilmiş, çalışma alanına kazandırılmak üzere hazır hale getirilmiştir. Gazeteler, faaliyet gösterdikleri dönemin en canlı tanıklarıdır. Bu belgeler tanık oldukları dönemin siyasi, sosyal, askeri ve eğitim gibi birçok konudan araştırılmasında ve aydınlatılmasında araştırmacıların sıkça başvurduğu kaynaklardır. Yayınlanan her gazetenin farklı bir ideoloji taşıyor olması da araştırmacıya çalışma boyunca yeni ufuklar açmakta araştırılan konuya değişik açılardan yaklaşma yeteneği kazandırmaktadır.

Araştırmamızın temelini oluşturan süreli yayın araçlarının küresel bağlamda gelişim sürecine kısaca bakacak olursak 15'inci yüzyılda matbaanın daha yaygın olarak kullanılmaya başlamasını bir başlangıç olarak kabul edebiliriz (Yılmaz, 2014: 5-10). Basım ve yayım faaliyetlerindeki bu devrimsel gelişmeye rağmen gazete ve gazetecilik faaliyetlerinin bugünkü anlamına ulaşması 16'ncı yüzyılı bulmuş, gazetelerin belirli periyotlarla süreli olarak yayınlanması ancak 17'nci yüzyılda ${ }^{1}$ gerçekleşmiştir (Karakütük, 2021: 2-4).

\footnotetext{
${ }^{1}$ Fransa'da 1631 yılında La Gazette adı ile çıkarılan yarı resmî yayın aracı bu alandaki gazete örneklerinin ilki olarak kabul edilmektedir.
} 
Süreli yayın araçlarının ülkemizdeki gelişimine baktı̆̆ımızda ise Takvim-i Vekayi adı ile çıkarılan resmî gazetenin bu yönde atılan ilk adım olduğunu görürüz². Takvim-i Vekayi, Sultan II. Mahmut tarafından kurulmuş ve batılılaşma çabaları doğrultusunda yapılan yeniliklerin basın yolu ile halka duyurulmasını hedeflemiştir. Osmanlı Devleti’nde daha sonra çıkarılan gazeteler biçimsel yapıları ve ilgi alanları itibarıyla Takvim-i Vekayi’nin takipçisi olmuştur (Koloğlu, 1994: 42). 1800’lü yılların ikinci yarısından itibaren bütün Osmanlı coğrafyasında basın hayatı açısından önemli gelişmeler yaşanmıştır. Namık Kemal, Ali Suavi gibi önemli gazeteciler yetişmiş ve bunlar kendilerinden sonra gelen kuşağı etkilemiştir. Basın hayatındaki gelişmelerin hızlanması üzerine 1864 tarihli Matbuat Nizamnamesi ve Ceza Kanunnameleri yayınlanarak basın üzerinde denetleyici bir tedbir uygulanmak istenmiştir (Koloğlu, 1994: 43).

İkinci Meşrutiyet'in ilanıyla birlikte basın-yayın hayatındaki gelişmeler daha da hızlanmıştır. $\mathrm{Bu}$ dönemde her görüşten, her fikirden onlarca yeni gazete ve dergi yayın hayatına başlamıştır (Koloğlu, 1994: 44). Gazeteciler 24 Temmuz 1908 günü gazetelerini sansür denetimine sokmadan piyasaya sürmüşlerdir. Bu fiili durumla gazeteciler kendileriyle ilgili basın rejimini değiştirmişlerdir (Özcan, 2011: 171). Sultan II. Abdülhamit döneminde İstanbul'da sayıs1 52 olan gazeteler, meşrutiyetin bahsettiğimiz bu değişim havası ile birlikte henüz 1909 yılında yedi katına, 377’ye, ulaşmıştır. Bütün ülkedeki gazete sayısı ise 120'den 730'a yükselmiştir (Koloğlu, 2014b: 19).

Süreli yayın araçlarının Millî Mücadele'nin başlaması ile birlikte yeni bir misyona büründüklerini görürüz. 19'uncu yüzyıldaki çağdaşlaşma sürecinde halkı çağın gereklilikleri konusunda bilinçlendirme misyonu üstlenen bu araçlar Millî Mücadele'nin başlamasıyla halk ile ordu arasındaki köprü olma görevini üstlenmiştir (Coşar, 1964: 140). Özellikle Millî Mücadele’yi destekleyen gazeteler harp muhabirleri aracılığıyla cepheden aktardıkları haberler ve Millî Mücadele'nin önde gelen isimleri ile yaptıkları özel röportajlar sayesinde askeri mücadelenin toplumsal alandaki sesi olmuştur. Bu gazeteler İstanbul'un İtilaf Devletleri tarafından denetim altına alınmasından sonra Anadolu'nun hemen her köşesine yayılmıştır (Güner, 1999: 17). Zor şartlar altında yayın hayatını sürdüren gazetelerden bazıları soba borularından toplanan isten hazırlanmış mürekkeple, bazıları vagonlarda, bazıları da sarı kâğıda baskı yaparak faaliyet gösterebilmiştir. Bu gazetelerin

\footnotetext{
${ }^{2}$ Osmanlı Devleti'nde ise basın tarihi genel olarak Takvim-i Vekayi ile başlatılmış olmakla birlikte bazı tarihçiler bunun Osmanlı Devleti'nin Mısır Valisi Kavalalı Mehmet Ali Paşa tarafından yarı Türkçe yarı Arapça olarak 1828'de çıkarılan Vekayi-i Mısriyye ile başladığını söylemektedir. Osmanlı Devleti’nin ilk resmî gazetesi olan Takvim-i Vekayi’yi takiben 1840 yılında İngiliz Morning Herald gazetesi muhabirlerinden William Churchill kapitülasyon hukuku sayesinde Osmanlı Hükümeti'nden edindiği gazete imtiyazı ile Ceride-i Havadis adında yarı resmi bir gazete çıkarmıştır. Osmanlı Devleti’nde ilk özel gazetecilik faaliyetleri ise 1860'ta Agah Efendi ve İbrahim Şinasi Efendi tarafından çıkarılan Tercüman-1 Ahval gazetesinin yayın hayatına başlaması ile olmuştur. Devlet desteği almadan kurulan bu ilk bağımsız fikir gazetesini 1862 yılında Tasvir-i Efkâr gazetesi izlemiştir (Yılmaz, 2014: 20-30). Vekayi-i Mısriyye ve Mehmet Ali Paşa'nın basın alanında yaptığı yenilikler hakkında ayrıntılı bilgi için Koloğlu (2014b: 19-20)'ye bakınız.
} 
hazırlanmasında çalışanlar zamanı geldiğinde kalemi bırakıp Kuva-yı Milliye saflarında savaşmış ve akşam tekrar gazetelerine dönmüş kişilerdir (Gezgin, 2007: 94).

\section{KONGRE’NIN DÜZENLENDİĞİ DÖNEMIN ASKERİ VE SIYYASİ VAZIYYETİ}

Birinci Dünya Savaşı devam ederken yapılan gizli görüşmeler ile Osmanlı toprakları çeşitli işgal bölgelerine ayrılmıştır (Erat, 2013: 72). Mondros Mütarekesi’nin savaşı resmen sona erdirmesi ile de Osmanlı toprakları hukuken işgale açık hale gelmiştir (Gündüz, 1973: 35). Savaşın sona ermesinden kısa süre sonra Anadolu’ya çıkan İtilaf Devletlerine ait birlikler hızlıca işgal girişimlerine başlamıştır (Armoğlu, 1993: 102). Osmanlı Hükümeti'nin bu durum karşısında ciddi bir varlık gösterememesi Türk milletini vatanın ve milletin korunması için harekete geçmek zorunda bırakmıştır (Atatürk, 1970: 13). Mustafa Kemal Paşa'nın İstanbul'dan Anadolu'ya geçmesi ile başlayan, Kazım Karabekir gibi önemli Paşaların onun etrafında toplanmasının ardından (Erat, 2016: 162) milli bir kurtuluş mücadelesine dönüşen bu hareket yeni ve bağımsız Türk devletinin de temeli olmuştur. Vatanın ve milletin kurtuluşu için başlatılan Millî Mücadele hareketi Erzurum ve Sivas Kongrelerinde örgütlenme sürecini tamamladıktan sonra (Sonyel, 2003: 213) Doğu Cephesi'nde Ermenilere, Batı Cephesi'nde ise 1'inci ve 2'nci İnönü Muharebeleri ile Yunanlılara karşı askeri başarılar elde etmiştir. Fakat Yunanlılar 10 Temmuz 1921 itibarı ile parolası Ankara'nın işgali olan yeni bir taarruz için harekete geçmiştir (Öztoprak, 2014: 257).

Batı Cephesi'nde askeri mücadele devam ederken Mustafa Kemal Paşa'nın girişimleri ile 15-21 Temmuz 1921 tarihleri arasında Ankara'da bir eğitim kongresinin toplanması kararlaştırılmıştır (Sarıhan, 2019: 9-10). Kongre başladığında Yunan ordusu Kütahya ve Afyonkarahisar'ı ele geçirmiş Eskişehir önlerine kadar gelmiştir. Kongre sırasında Türk ordusunun Sakarya nehrinin doğusuna çekilmek üzere manevra yapması üzerine yüzlerce yıllık kadim Türk şehri Eskişehir de Yunanlıların eline geçmiştir. Bu durum Ankara'da büyük tepki ile karşılanmış o günlerde bazı gönüllü mebuslar cepheye gitmeye başlamıştır (Sarıhan, 2019: 20-21).

\section{KONGRE ÖNCESİNDEKİ HABERLER}

Ankara' da Maarif Kongresi'nin toplanacağına yönelik ilk haberler, 1921 mayısının sonundan itibaren gazete sayfalarında yer almaya başlamıştır. Ankara Hükümeti’nin yarı-resmi yayın aracı niteliği taşıyan Hakimiyet-i Milliye gazetesi, 31 Mayıs 1921 tarihli sayısının ikinci sayfasında "Maarif Kongresi” başlığı ile temmuz ayının 15'inde Ankara'da bir Maarif Kongresi toplanacağını ve bu kongre ile eğitim işlerinin yeniden düzenleneceğini duyurmuştur. Haberin detaylarında Kongre’ye Ankara'ya yakın olan il merkezlerinin hepsinden, uzak olan illerin ise bazılarından katılımların olacağı belirtilmiştir. Buna göre Ankara’ya yakın her ilin merkezinden Maarif Müdürü, Daru'l-muallimin müdürü ve Sultani Müdürü; Daru'l-muallimin olmayan yerlerden ise tedrisat-1 iptidai müfettişi, sultani 
olmayan yerlerin de idadi müdürü Kongre'ye gelecektir (Hakimiyet-i Milliye, 1921: 2). Hakimiyet-i Milliye yaptığı haber vesilesi ile Maarif Vekâlet'inin bu teşebbüsünü memleketin irfan hayatında pek mühim bir hareket olarak gördüğünü belirtmiş, bundan dolayı da Maarif Vekaleti'ne tebriklerini iletmiştir.

Hakimiyet-i Milliye gazetesinde yer alan bu haberin detaylarından Kongre'de genel olarak şu konuların görüşüleceği anlaşılmaktadır: Öğretmen sayısının nüfusa oranla bölgelere dağılımı, bir bölgede bulunan okulların miktarı ve dereceleri, okul binalarının ve öğretmenlerin adedi, öğretmenlerin dereceleri, öğrencilerin adedi ve dereceleri, öğrenci velilerinin tuttukları iş, kız okullarının miktarı ve dereceleri, kız okullarının öğrencilerine karşı halktaki genel tutum, Meşrutiyet'ten beri memlekette eğitime yönelik ortaya çıkan değişmeler, ziraat ve sanayi okullarının durumu, sıbyan mektepleri, vakıf medreseleri, mahalli eğitim, ders kitapları ve eğitim-öğretim programının hazırlanması... (Hakimiyet-i Milliye, 1921: 2). Ayrıca köy okullarına öğretmen yetiştirilmesi, ilk ve orta dereceli okulların öğretim programlarının hazırlanması Kongre'nin toplanmasındaki temel amaçtır (Akyüz, 2008: 320-323).

Hakimiyet-i Milliye gazetesinin 3 Haziran 1921 günlü sayısında yayınlanan başka bir haberde ise "Maarif Kongresi” başlığı altında Kongre'nin önemine ve niteliğine dair genel bir sohbet yazısı yer almıştır. Yazıda, "Fertlerin hayatı gibi milletlerin hayatı da baştanbaşa bir savaş, fasılasız devam eden bir kavga demektir. Cephelerdeki muvaffakiyeti ne zaman cephe gerilerindeki muvaffakiyetle tamamlarsak, cephelerde bir senedir kurulan ordunun himmetini ne zaman cephe gerisinde mücehhez bir muallim ordusunun verimli faaliyeti ile ikmal edersek, o zaman bekamıza ait hazırlıkları düzenlemiş oluruz." sözü ile başarıya ulaşmış silahlı mücadelenin ancak eğitim ile desteklendiği takdirde gerçek bir zafer olacağı üzerinde durulmuştur. Buna örnek olarak ise Alman General Moltke'nin (Helmuth Karl Bernhard Von Moltke) 1866-1871 yıllarında önce Avusturya sonra da Fransızlar ile yaptığı savaşlar sonucunda elde ettiği zaferlerden sonra söylediği “Bu zaferleri Prusya muallimleri kazanmıştır." sözüne atıf yapmıştır. Yazının devamında milletleri muzaffer eden iki esas unsur olduğundan bahsedilmiş bunların da askerler ve öğretmenler olduğu belirtilmiştir. Ayrıca, "Memleketleri fethetmenin usulü bir değil, ikidir. Ordu ve mektep! Ne vakit ki mektep orduya yardım etmez, ne vakit ki ordu zaferini mektep fütuhatı takip etmezse, mutlaka o zafer boşa gitmiş, o fetih akamete uğramıştır. Eğer vaktiyle yeniçerilerin ta Viyana'ya kadar yürüyüp zapt ettiği ülkeleri mektep ve maarif kudretiyle de ele geçirmeye çalışsaydık, oralardan belki bu kadar seri dönmezdik." sözleri ile tarihte yapılan yanlışlardan ders çıkarılması gerektiği belirtilmiştir (Hakimiyet-i Milliye, 1921: 2). Aynı yazıda Kongre'nin Türk eğitim tarihinde ilk olmasının önemi, Kongre'de alınacak kararlar ve Kongre'nin geleceğe yönelik toplumda uyandırdığı heyecana yönelik ise şu ifadeler yer almıştır: “ $B u$ 
Kongre, Türk hükümet hayatında ilk defa olarak mektep ve tahsil namına mevcudumuzun neden ibaret olduğunu öğretecek, mektep ve tahsil için mesaimizin istikametini tayin edecektir. Kongre'de toplanacak liva murahhasları kendi mıntıkalarının bugünkü maarifine ait malumat verecekler ve geleceğe ait müşterek maarif programını münakaşa edeceklerdir. Memleket maarifinde vahdet temin etmek, terbiye ve tedris usullerini ortak bir esasa bağlamak, çocuklarımızı hususi içtihatlara göre yetiştirmekten kurtarmak, velhasıl müş̧erek ve mütecanis evsaf ile mücehhez bir nesil yetiştirmek ancak bu gibi kongrelerin vereceği firsatlardan istifade ile tahakkuk eder. Bu itibarla Maarif Kongresi, Anadolu irfanı için adeta bir pusula vazifesi görecektir. Maarif Vekâleti, bu Kongre teşebbüsüyle mekteplerini hayalî ve soyut şeyler ile değil, müspet ve muayyen mevzular üzerinde muallimlerinin vereceği hakiki malûmat ile yürütmek hususundaki niyetini gösteriyor. Bu güzel niyeti takdir etmek bir vazifedir."

Hakimiyet-i Milliye gazetesi 10 Temmuz 1921 tarihli sayısında Kongre'ye yönelik "Muallime ve Muallimler Konferansı" başlığı altında topladığı haberlerinde Kongre'nin bir hafta donra Ankara'da başlayacağını bir kez daha hatırlatmıştır (Hakimiyet-i Milliye, 1921: 1). Gazete, 13 Temmuz'da ise ikinci sayfasında yer alan “Dahili Haberler” kısmından verdiği haberde Kongre’ye davet edilen eğitim görevlilerinin peyderpey Ankara'ya gelmeye başladığını ve bu misafirlerin Sultani Mektebi’nde ağırlandığını belirtmiştir (Hakimiyet-i Milliye, 1921: 2). Bir sonraki gün (14 Temmuz 1921) yayınlanan sayıda ise "Maarif Kongresi”" başlığı altında 15 Temmuz'da toplanacak olan Kongre'nin muhtelif konuları görüşmek üzere Daru'l-muallimin Kongre Salonu'nda öğleden sonra saat üçte açılacağı bilgisi yer almıştır. Haberde ayrıca Kongre'nin açılış konuşmasını BMM Reisi Mustafa Kemal Paşa’nın gerçekleştireceği ifade edilmiştir (Hakimiyet-i Milliye, 1921: 2).

Vakit gazetesi ise 14 Temmuz 1921 tarihli nüshasının ikinci sayfasında “Anadolu Haberleri” kısmında “Ankara'da Müsamereler” başlı̆̆ı ile Kongre'nin 15 Temmuz'da toplanacağını okuyucusuna duyurmuştur. Gazete aynı sayfada yer alan "Mezuniyet Layihası” başlıklı haberinde ise Kongre'nin toplanması ile Ankara'da "Halk Mektepleri” teşkilatı yapılmak istendiğini belirtmiştir. Haberin içeriğinde Kongre'nin alacağı kararlar doğrultusunda yapılacak düzenlemeler ile iptidailerin eğitim süresinin kısalacağı gibi gerek iptidailerin gerekse idadilerin tahsil ve terbiyesinin daha işe vuruk olacağı bilgisi yer almıştır (Vakit, 1921: 2). Aynı gün çıkarılan Tercüman-ı Hakikat gazetesinde “Maarif Bütçesine Zam” başlığı ile 1921 yılı için Maarif Teşkilatı’na ayrılan bütçeye 4500 lira ek bütçe tahsis edildiği böylece Kongre'de alınacak kararlara finansman sağlandığı aktarılmıştır (Tercüman-1 Hakikat, 1921: 2). Tercüman-1 Hakikat'in bu haberine benzer bir habere 15 Temmuz 1921 günü çıkarılan Tevhid-i Efkâr gazetesinde de "Maarif Bütçesine Tahsisat İlavesi” başlığı ile yer verilmiştir (Tevhid-i Efkâr, 1921: 2). 
15 Temmuz 1921 tarihli Anadolu'da Yeni Gün gazetesinde yer alan haberlerde "Yeni Devir ve Türkiye" başlığı altında dünya medeniyetinin eğitimden sanayiye, tarımdan ticarete birçok alanda değişmiş olduğu, değişen şartlar doğrultusunda çağı yakalayabilmek için yapılması gereken işlerin neler olabileceği sorgulanmıştır. Yazıda gelișen ve değișen dünyada Türkiye'nin konumunu eğitimsel açıdan tartışmaya açan gazete, yeni şartlara uygun bir hayat sürebilmek için eğitim konularında çağa uygun modern yeniliklerin yapılması gerektiği üzerinde durmuştur (Anadolu'da Yeni Gün, 1921: 1).

\section{KONGRE SÜRECINE VE ALINAN KARARLARA YÖNELİK HABERLER}

15 Temmuz 1921 sabahının erken saatlerinden itibaren Anadolu'nun farklı yerlerinden gelen eğitimciler Kongre'nin düzenleneceği Daru'l-muallimin Konferans Salonu'nda toplanmaya başlamıştır. Açıksöz gazetesi “Muallime ve Muallimler Konferansı” başlıklı haberi ile Kongre’nin bu ilk gününe dair önemli detaylar paylaşmıştır. Haberde Kongre’nin Mustafa Kemal Paşa'nın konuşması ile açıldığından ve Kongre'ye Anadolu'nun her tarafından iki yüzü aşkın azanın iştirak ettiğinden bahsedilmiştir. Haberin detaylarına göre, Kongre'ye başkanlık eden Mustafa Kemal Paşa katılımcıların ellerini tek tek sıkmış ve Kongre'de yaptığı nutukta, vatanın selameti için silahlı mücadele kadar ilmi mücadelenin de pek mühim olduğunu belirtmiştir. Milletin hem askeri hem de ilmi sahada iki cephede birden mücadele ettiğini belirten Paşa her iki sahada da muzaffer olunacağına dair inancını ifade etmiştir. Paşa'nın bu konuşması katılımcılar tarafından şiddetle alkışlanmıştır (Açıksöz, 1921: 1).

Kongre'nin ilk gününe dair Açıksöz gazetesinde yer alan haberlere ek olarak Hakimiyet-i Milliye gazetesinde ise kongre binasının ve çevresinin Türk bayrakları ile donatıldığı ve Ankara'ya bu Kongre sebebiyle bir bayram havasının hâkim olduğu belirtilmiştir. Gazeteye göre Mustafa Kemal Paşa öğleden sonra saat üçte kongre salonuna gelmiştir. Maarif Vekili Hamdullah Suphi Bey tarafindan kongre azaları birer birer Mustafa Kemal Paşa hazretlerine takdim olunmuştur. Bu takdim merasiminin ardından Mustafa Kemal Paşa tarafından öğretmenlere ithafen aşağıda nakledilen mühim ve pek kıymetli nutuk gerçekleştirilmiştir (Hakimiyet-i Milliye, 1921: 1; Açıksöz, 1921: 1; Anadolu'da Yeni Gün, 1921: 1):

Muhterem Hanımlar, Efendiler.

Harb-i Umûmî memleketimize bir mağlubiyet getirdi. Düşmanlarımız bunu vesile bilerek milletimizi tamamen imhâ etmek istediler. Buna karşı meydana gelen Millî Mücadele ruhuna Ankara'da muazzam bir sahne oldu. Bizi yaşatmamak isteyenlere karşı yaşamak hakkımızı müdafaa etmek üzere toplanan Türkiye Büyük Millet Meclisi, burada, Ankara'da toplandl. Bugün Ankara milli Türkiye’nin milli ĕgitimini kuracak olan Türkiye Muallime ve Muallimler Kongresi’nin toplantısına sahne olmakla da iftihar etmektedir. Asırlarca süren mücadelelerin ortaya çıkardı̆̆ı ă̆ır yüklerin devletimizde meydana 
getirdiği yaralarl tedavi için harcanacak himmetlerin en büyüğü hiç şüphesiz irfan yolunda harcananlardır. Gerçi bugün maddi ve manevi kuvvet kaynaklarımızı, milli sınırlarımız dahilindeki memleketlerimizde işgalci bulunan düşmanlara karşı kullanmak mecburiyetindeyiz. Irfan-ı memleket için tahsis edilebilen şey, müstakbel maarifimize dayanak noktası olacak bir temel kurmăga kâfi değildir. Ancak vâsi ve kâfi şartlar ve vasitalara malik oluncaya kadar geçecek mücadele günlerinde dahi kemal-i dikkat ve itina ile işleyip çizilmiş bir milli terbiye programı vücuda getirmeğe ve mevcut maarif teşkilâtımızı bugünden verimli bir faaliyetle çalıştıracak esasları hazırlamaya mesai sarf etmeliyiz. Şimdiye kadar takip olunan tahsil ve terbiye usullerinin milletimizin gerileme tarihinde en mühim bir amil olduğu kanaatindeyim. Onun için bir milli terbiye programından bahsederken, eski devrin hurafelerinden ve fitri niteliklerimizle hiç de münasebeti olmayan yabancı fikirlerden, şarktan ve garptan gelen bilcümle tesirlerden tamamen uzak, milli tarihimize yakışan bir kültürü kastediyorum. Çünkü milli davamızın başarıya ulaşması, ancak böyle bir kültür ile temin edilebilir. Olduğu gibi alınan bir ecnebi kültürü, şimdiye kadar takip olunan yabancı kültürlerin yıkıcı neticelerini tekrar ettirebilir. Kültür milli fikirlerimize dayanan zeminle oluşturulabilir. O zemin, milletin öz karakteridir. Çocuklarımız ve gençlerimiz yetiştirilirken onlara bilhassa mevcudiyeti ile hakkı ile birliği ile taarruz eden bilumum yabancı unsurlarla mücadele lüzumu ve efkârı milliyeyi kemali istiğrak ile her mukabil fikre karşı şiddetle ve fedakârane müdafaa zarureti telkin edilmelidir. Yeni neslin bütün kuvveyi ruhiyesi bu evsaf ve kabiliyetin zerki mühimdir. Daimî ve müthiş bir mücadele şeklinde tebarüz eden hayat-ı akvamın felsefesi, müstakil ve mesut kalmak isteyen her millet için bu evsafi kemal-i şiddetle talep etmektedir. Teferruatını tamamen erbab-l ihtisasına bırakmak istediğim bu mesele hakkındaki umumi nokta-i nazarımı ikmalden ifade için yeni neslin teçhiz olunacă̆ı evsaf-ı maneviye meyanında kuvvetli bir aşk-ı fazilet ve kuvvetli bir fikri-i intizam ve inzibattan da bahsetmek zaruretindeyim. İşte biz, bu Kongre’nizden yalnız, çizilmiş eski yollarda alelade yürümenin tarzı hakkında müdavele-i efkâr etmeği değil belki serdettiğim şartları haiz yeni bir sanat ve marifet yolu bulup millete göstermek ve o yolda yeni nesli yürütmek için rehber olmak gibi mukaddes bir hizmet bekliyoruz. Maarif Vekâlet'inin halkı tanımış, muhiti ve memleketi takdir etmiş muallim ve mütehasslslardan mürekkep bir ilim ve irfan kongresini Ankara'da toplamă̆ düşünmüş olmasını ve bugünkü zor şartlara rağmen bu teşebbüsünde muvaffak olmuş bulunmasını kemal-i takdir ile yâd ederim. Huzurunuzda ve huzur-ı millette millî maarifimiz hakkındaki nokta-i nazarımı ifadeye imkân veren bu vesileden istifade ederek geleceğimizin kurtuluşunun aziz öncüleri olan Türkiye muallime ve muallimleri hakkındaki hürmet dolu hislerimi zikretmek isterim. İstikbal için hazırlanan vatan evlatlarına, hiçbir zorluk karşısında teslim olmayarak, kemâl-i sabır ve metanetle çalışmalarını ve tahsildeki çocuklarımızın ebeveynine de yavrularının ikmal-i tahsil için her fedakârlıktan kaçınmamalarını tavsiye ederim. Büyük tehlikeler önünde uyanan milletlerin ne kadar sebatkâr 
oldukları tarihen müspettir. Silâhıyla olduğu gibi, dimağıyla da mücadele mecburiyetinde olan milletimizin birincisinde gösterdiği kudreti ikincisinde de göstereceğine asla şüphem yoktur. Milletimizin saf seciyesi istidat ile doludur. Ancak bu tabiî istidadı inkişaf ettirebilecek usullerle mücehhez vatandaşlar lâzımdır. Bu vazife de sizlere teveccüh ediyor. Hükümet-i Milliye'miz, kemal-i ciddiyet ve samimiyetle arzu ettiği derecede Türkiye muallime ve muallimlerinin hayat ve refahını henüz temin edememekte olduğunu bilirim. Fakat milletimizi yetiştirmek gibi mukaddes bir vazifeyi yerine getiren yüce heyetinizin bugünün vaziyetini nazar-ı itibara alacağından ve her zorluğa göğüs germe ile bu yolda gayet metanetle yürüyeceğinden şüphem yoktur. Vazifeniz pek mühim ve hayatîdir. Bunda muvaffak olmanızı Cenabı Hakk'tan temenni ederim.

Şiddetli alkışlarla karşılanan bu mühim nutka, Kongre'ye katılım gösteren öğretmenler adına Sivas Maarif Müdürü Osman Nuri Bey bir cevabi nutuk okumuştur (Sarıhan, 2019: 86-88).

Reisimiz Paşa Hazretlerimiz!

Şu giriştiğimiz milli mücahedede biz muallimlerin nokta-i nazarı vahdet-i milliyeyi takviyeye çalışmaktadır. Büyük milletimiz muhtelif isimler altında birçok parçalara ayrılmış, kendi şuurunu daha büsbütün elde edinceye kadar Anadolu Türklüğ̈̈nü büyük fikrin manevi bayrağı altında toplamak bizim en büyük emelimizdir. Biz hiçbir mahrumiyetten müşteki değiliz. Çektiklerimiz ve çekeceklerimiz şahsi ve mesleki emellerin fevkinde olan memleket için bir borçtur. Biz birçok mahrumiyetler içinde kalsak yine vazifemize kemal-i huzur-ı kalple seve seve devam edeceğiz. Milletimizin mazisine ait ezeli büyüklüğ̈̈ne olduğu gibi istikbaline ait ebedi büyüklüğüne de eminiz. Bize bu emniyeti veren vesilelerden biri de mekteplerimizdeki tecrübelerimiz, çocuklarımızda gördügü̈müz harikulade istidattır. Maarifimiz hükümet-i milliyemizden himaye ve sahabet gördükçe topraklarımızda asri ve milli bir hayat-ı irfan tecelli edecektir. Paşa hazretleri, Aziz Vekilimiz Hamdullah Suphi Beyefendi'nin delaletleri ile ilk defa teşekkül eden Kongre'mizin zat-ı devletleri tarafindan küşadı bizi ayrıca mesut ve mağrur etmiştir. Uzun senelerin seyyiat-ı idariyesinden sonra büyük harbe girmiş ve nihayetinde harap olmuş ve kimsesiz kalmış olan vatanımız, galiplerin, onların teşvikatını gören dahili düşmanların her gün yeni bir hakaret ve istilasına uğrarken siz yüksek dehanız ve yüksek imanınızla ortaya çıktınız ve milletin başına geçtiniz. Bugünkü milli hükümet ve milli mücahedeyi vücuda getiren muazzam harekete aşk ve hürmetle sevilen bir rehber oldunuz. Askerlerimiz, milli kahramanımızın rüyasını hakikate kalp eden bir iman ile zaferden zafere koşuyorlar. Büyük millet meclisinin merkezinde hayatı ebedi olan milletimizin emsalsiz kahramanını dava-yı millimizin bin kere aziz timsalini selamlamakla bahtiyarız. Nutkunuzun manası meslekte imanımızın ve gayemizin ruhunu pek beliğ bir surette ifade etmiştir. Biz bu esasa sadığız. Reis Paşa Hazretleri Kongre'mize riyaset buyurmanızdan dolayı duyduğumuz derin hiss-i şükranın arzına müsaadenizi rica ederiz. Bu 
hareketinizle ifade ettiğiniz fikir hepimiz tarafindan bütün manasıyla anlaşılmıştır. Bu içtimaımızdan bi’l-istifade Anadolu mücahedesini idare eden büyük millet meclisine ve onun emir ve irşadiyla bütün beşeriyetin gözü önünde harikalar gösteren milli ordumuza selam-ı takdis ve hürmetimizi yollarız. Açtı̆̆ınız necat yolunda vazifemiz muayyendir. Milletin evladını seciye, iman ve aşk-ı milli ile mücehhez olarak yetiştirmeye çalışırken bugünkü sözlerinizi daima hatırlayacağımıza itimat buyurunuz.

Osman Nuri Bey'in konuşmasından Mustafa Kemal Paşa'nın Türk halkına yol göstericiliğinin öğretmenlerce kesin olarak kabul edildiği ve öğretmenlerin onun gösterdiği yolda ilerleyecekleri açıkça anlaşılmaktadır (Alp, 2020: 4). Bu nutuk son bulduktan sonra İstanbul'da senelik kongrelerini akdetmekte olan Muallimler Cemiyeti Heyeti Umumiye Riyaseti ${ }^{3}$ tarafindan Kongre'ye gönderilen ve Kongre'nin toplanmasından dolayı duyulan memnuniyeti dile getiren bir mektup okunmuştur (Hakimiyet-i Milliye, 1921: 1; Açıksöz, 1921: 1).

Ankara Maarif Kongresi Riyâset-i 'Âliyyesine

Bütün muallimlerini sıkı bir kalp ve dimâ̆g ittihâdı ile bir teşkîlât altına almak için toplanan İstanbul Muallimler Cemiyeti Heyet-i Umûmiyesi bugün Türk harikalarının mihrâk-ı intişârı olan Ankara'mızda toplanarak maarif siyâsetinde yeni bir devrin doğuşunu tebşîr edecek heyetinizi hürmet ve hasretle selâmlamak istemiş ve bu şerefli vazifenin îfâsını bendenize tevdî' eylemiştir. Millî irfânın lâyezal bir istiklâl içinde inkişâfı mücâhedelerinin hedefini teşkîl eden bu muallimler, kalplerinden ve dimâğlarından ibaret bir silah ile kânî ve mutmain seyirlerinden âfâkın infilâkını bekler ve görürlerken üstlerine açılan geniş rahmet kubbesinin büyük bir 'âlemi birden ihâta ettiğini düşünerek müteselli ve münşerih olmaktadır. O büyük âlemi ki Teâlâ onu ayrılmak ve ayrı yaşamak için yaratmadı. İstanbul Muallimler Cemiyeti bu müttehid hâl ve istikbâlin emrettiği kudsî vazîfede maddî ve manevî Türk varlığını temsil iden heyetinize muvaffakiyetler dilediği sırada millî irfânı yabancı tasallutlardan kurtarmak ve korumak için yakında akd edilecek umûmî kongrede klymetdâr müzâheretlerine istinâd ittiğini arz eder.

\section{İstanbul Muallimler Cemiyeti Heyet-i Umûmiye Reisi Hakkı Tarık}

Kongre'nin ilk gününe yönelik Anadolu'da Yeni Gün gazetesinde yer alan haberde ise "Muallimler Konferansı Açıldı" başlığı ile şu ifadeler yer almıştır: "Cephe-i harpte hak, mevcudiyet ve

\footnotetext{
${ }^{3}$ 1908'de İstanbul'da Encümen-i Muallimin Cemiyeti ile başlamış olan muallim örgütlenmesi 1908-1920 yıllarında pek çok muallim cemiyetinin kuruluşuna öncülük etmiștir. Bu cemiyetlerden biri olan Muallimler Cemiyeti 8 Mart 1918'de Ahmet Halit (Yaşaroğlu) tarafından kurulmuştur. Öğretmenler arasında dayanışmayı sağlamak, halkın kültür düzeyini yükseltmek gibi önemli amaçlarla açılan Cemiyet, kuruluşunun ilk yıllarından itibaren faaliyetlerini İstanbul Türk Ocağı binasında sürdürmüştür. Muallimler Cemiyeti, halkın, öğrenci ve öğretmenlerin aydınlatılması konusunda gazetelerde yazılar yayınlamıș, işgal kuvvetleri karşısında mitingler düzenlemiş ve pek çok şehirdeki şubelerinin yayın faaliyetleri ile Millî Mücadele'ye önemli katkılar sağlamıştır (Alp, 2020: 3)'den (Göldaş, 1981: 1-28).
} 
hürriyetimizi müdafaa eden kahraman harp ordusu kadar vazifesi mühim olan muallim ordusu teşkilatı vücuda getirecek hür Türkiye’nin hür maarifinin temelini kuracak Türkiye Muallimler Kongresi'nin resmi açılışı cuma günü Ankara Daru'l-muallimin salonunda gerçekleştir." Gazetenin haberine göre resmi konuşmalar saat dörtte sona ermiş ve saat beşe kadar salondakiler kendi aralarında konuşmaya devam etmiştir. Saat beşten sonra ise Anadolu lokantasında kongre azalarına bir çay ziyafeti tertip edilmiştir. Gazete bu haberinde Hamdullah Suphi Bey ve Mustafa Kemal Paşa'nın portrelerine de yer vermiştir (Anadolu'da Yeni Gün, 1921: 1).

Anadolu'da Yeni Gazetesi'nin 18 Temmuz 1921 tarihli nüshasında da Kongre’ye dair önemli bilgiler yer almıştır. "Maarif Kongresinde Yeni Tedrisat-1 İptidaiye Programı” başlığı ile sunulan habere göre Kongre'nin ikinci toplantısına Maarif Vekili Hamdullah Suphi Bey başkanlık etmiştir. Bugün yapılan toplantılar sonucunda sekiz senelik yeni bir öğretim programı hazırlanmış ve uygulanmasına karar verilmiştir. Yeni programa itiraz edenlerin temel eleştirileri ise eski altı senelik programın dört seneye sıkıştırılmış olmasına ve din dersine ayrılan saatlerin az olmasına yönelik olmuştur. Ayrıca gazetenin bugünkü sayısında İstanbul Muallimler Cemiyeti'nin Kongre'ye gönderilen -önceki sayfada belirttiğimiz- mektubuna “Ankara'da toplanan muallime ve muallimler kongresine hitaben gönderdiğiniz mektup ilk içtimaımızda okundu. Meslektaşlarınız yazdıklarınızdan dolayı en derin mesut bir tesir duydular. " cevabının verildiği belirtilmiştir (Anadolu'da Yenigün, 1921: 1).

Kongre'nin devamına yönelik 18 Temmuz 1921 tarihli Hakimiyet-i Milliye gazetesinde "Yeni İptidai Programının Münakaşası” başlığı ile aktarılan haberde, Maarif Vekili tarafından Halk Mektepleri hakkında hazırlanan programın tartışmaya açıldı̆̆ı bilgisi yer almaktadır. Buna göre Maarif Vekaleti adına projeyi ilk tedrisat müdürü Ahmet Edip Bey Kongre'ye katılanlara izah etmiştir. Projede iptidai eğitim dört seneden ibaret olup bu dört senelik tahsil süresinden sonra bu kademeyi tamamlamak için bir sınıf daha ilave olunmuştur. Ahmet Edip Bey, bu düzenlemenin maksadını "Çocuklarımızı hayat-ı amaliyede muvaffak olacak bir kabiliyette yetiştirmek için bu yolda bir program tanzimine lüzum görülmüştür." ifadesi ile açıklamıştır. Hakimiyet-i Milliye'nin haberinde yer alan detaylara göre Ahmet Edip Bey’in bu konudaki görüşlerini izah etmesinden sonra birçok aza konuşma yapmak için söz almıştır. İlk söz alan Akşehir İdadisi Müdürü Hayrettin İlhan Bey şimdiye kadar tatbik edilmiş olan tedrisat-ı iptidaiye programlarının uygulanmasının mümkün olmadığını söylemiştir. Buna örnek olarak da ahalinin altı senelik iptidai mekteplerine tahammülünün olmadığını ve bu mekteplerde okutulan birçok dersin halk tarafından lüzumsuz görüldüğüne bu nedenle de halkın büyük kesiminin mahalle mekteplerine başladığını söylemiştir. Hayrettin İlhan Bey halkın eğitimi için böyle yoksun programlar yerine köylünün en ziyade muhtaç olduğu ve istediği din, hesap, ziraat vb. derslerin okutulmasının daha gerçekçi olacağını ifade etmiştir (Hakimiyet-i Milliye, 1921: 1). Kongre'nin ikinci 
gününde yapılan tartışmalarda Eskişehir Daru'l-muallimin Müdürü Ekrem Bey ise köylü ile şehirlinin ihtiyaçlarının farklı olması nedeniyle köylü için ayrı şehirli için ayrı iptidai programlarının hazırlanması gerektiğini savunmuştur. Eskişehir İdadisi Almanca Öğretmeni Selahaddin Bey de konuşmasında Maarif Vekaleti'nin hazırladığı programı hayati derslere ehemmiyet vermiş olduğundan dolayı muvaffak gördüğünü söylemiştir (Hakimiyet-i Milliye, 1921: 1).

Gazete haberlerine göre Kongre'de görüşülen bir diğer önemli konu da meslek dersleri programıdır. $\mathrm{Bu}$ konuda şimdiye kadar başka ülkelerin programlarından alınarak uygulanan meslek dersleri için ülkemizin şartları doğrultusunda program hazırlanması kararı alınmıştır. Konu hakkında konuşmak üzere söz alan Daru'l-muallimat Müdiresi kız mekteplerinin programlarına kızlarımızın ev kadını olabilmek için lazım olan amali meşguliyetlere yönelik derslerin konulmasının gerekliliğini belirtmiştir. Kongre'nin sonunda Hamdullah Suphi Bey tedrisat-1 iptidai ve meslek dersleri programı hakkında gün boyunca cereyan eden bu müzakereleri Kongre'nin oylamasına sunulmasını istemiş ve oylama sonucunda büyük bir çoğunlukla kabul edilmiştir (Hakimiyet-i Milliye, 1921: 1).

Devam eden Kongre hakkında Vakit ve Anadolu' da Yeni Gün gazetelerinde yer alan çeşitli haberlerde ise Kongre'nin toplanmasındaki asıl amacın "Halk Mektepleri” projesini hayata geçirmek olduğu üzerinde durulmuştur. Vakit gazetesi, "Halk Mektepleri” başlığı altında derlediği haberinde Halk Mektepleri teşkilatının merkezinin Ankara'da olacağını dolayısıyla da gelecekte Ankara'nın bir eğitim merkezi haline getirileceğini aktarmıştır. Bu projenin hayata geçirilmesi ile iptidailerden başlanarak bütün eğitim sisteminin toplumun ihtiyaçlarına cevap verir hale getirilmesi, daha işe vuruk ve hayata dönük olmasının amaçlandığı belirtilmiştir. Bu sayede çocuklarımızın hayata daha iyi hazırlanacağı ve kendi ihtiyaçları doğrultusunda eğitim alma imkanına sahip olacakları ifade edilmiştir (Vakit, 1921: 2). Halk Mektepleri projesi ile ayrıca iki önemli unsurun daha hayata geçirileceğinin belirtildiği haberde bunlardan birincisinin, halkın okur yazarlığının çoğaltılması, ilmi ve fenni tahsilin gayelerinin temin edilmesi; ikincisinin de halka hayat mücadelesinde işine yarayacak, coğrafyanın özellikleri doğrultusunda eğitim programının hazırlaması ve işçi mektepleri vücuda getirilmesi olduğu belirtilmiştir (Anadolu'da Yeni Gün, 1921: 2).

21 Temmuz 1921 tarihli Anadolu’da Yeni Gün gazetesi “Maarif Kongresi” başlıklı haberinde dün (20 Temmuz 1921) saat 12.00'de Kongre'nin Maarif Vekili Hamdullah Suphi Bey riyasetinde dördüncü ve son toplantısını gerçekleştirdiğini belirtmiştir. Son toplantıda daha önce alınan bazı kararların yeniden gözden geçirildiğini belirten gazete öğleden sonra saat ikide Kongre'nin Reis Hamdullah Suphi Bey’in kapanış nutkuyla sona erdiğini aktarmıştır (Anadolu’da Yeni Gün, 1921: 2). 
Hakimiyet-i Milliye gazetesi de 22 Temmuz 1921 tarihli nüshasında "Maarif Kongresi” başlıklı haberi ile Kongre'deki çalışmalara bugüne kadar iki yüz elli muallime ve muallimin katıldığını belirtmiştir. Haberde yaşanan tartışmalarda bütün muallimlerin Maarif Vekaleti'nin eğitimi sadeleştirmek, hayata dönük hale getirmek ve mahallileştirmek hususundaki düşüncesinde fikir birliğinde olduklarını aktarmıştır. Haberin detaylarında, Maarif Vekili'nin Kongre'nin sonunda yaptığı konuşmada Kongre'de alınan kararların eğitim alanında olduğu kadar kültür ve sanat alanında da etkili olacağını dile getirdiği belirtilmiştir. Buna göre eski Anadolu'nun sanat itibarı ile bütün dünyada umumi bir şöhrete mazhar olduğu ve yapılan yeni program ile bu sanat merkezlerinin yeniden uyandırılmasının ve memleket hayatına kazandırılmasının hedeflendiği belirtmiştir (Hakimiyet-i Milliye, 1921: 2).

\section{KONGRE'NINN YARATTIĞI ETKILLERE YÖNELİK KÖŞE YAZILARI}

Millî Mücadele'nin en hareketli günlerinde düzenlenen bu Kongre vatanın dört bir tarafinda coşku ve ümitle karşılanmıştır. Daha önce belirttiğimiz Sivas Maarif Müdürü'nün Kongre’de yaptığı konuşma ve Muallimler Cemiyeti'nin Kongre’ye göndermiş olduğu mektuptan da bu durum anlaşılmaktadır. Ancak burada asıl üzerinde durulması gereken konu bu Kongre'nin toplum nezdinde nasıl bir karşıllk bulduğudur. Onlarca yıldır savaşın içerisinde olan bir halk ve o halkı tamamen imha etmek üzere Türk vatanına saldırmış bir düşman... Uzun savaş yıllarının getirdiği yokluk ve bu yokluğa rağmen elinde kalan son varlıklarını da orduya teslim etmiş bu halk, içinde bulunduğu zor zamanlarda bir eğitim kongresinin toplanmasına nasıl bir tepki vermiştir. Halkın, Millî Mücadele’nin en keskin zamanlarında düzenlenen bu Kongre'ye yönelik tutumunu en açı şekilde ortaya koyacak olan belgeler hiç şüphe yok ki dönemin psiko-sosyal havasını en iyi yansıtan ulusal ve yerel medyada yayınlanan köşe yazılarıdır. Halk ile bir bütün haline gelen köşe yazarları, cephedeki muhabirlerden gazetelerine servis edilen son dakika haberlerini; halkın bu haberlere verdiği tepkiler ile sentezleyerek dönemin ordu ve millet arasında oluşan bağını köşelerinden aktarmıştır.

Yukarıda sözünü ettiğimiz gibi 1921 Maarif Kongresi'nin toplum tarafından nasıl karşılandığını anlayabilmek için öncelikle halkın sesi olmayı hedefleyen medya araçlarına bakmamız gerekiyor. Örneğin Açıksöz gazetesi yazarlarından İsmail Habip Bey “İçteki Harp” başlığı ile yayınladığı makalede, Kongre'yi işaret ederek cephede verilen mücadelenin yanı sıra asıl mücadelenin yurt içinde cehalete karşı verilmekte olduğunu belirtmiştir. İsmail Habip, bu durumu Millî Mücadele'yi idare eden liderlerin zafere olan inancının açık bir ispatı olduğunu ifade etmiştir (Habip, 1921: 1):

Dıştaki harbi hep biliyoruz! Düşman hazırlayabileceği kadar şeyi hazırlamış, yapabileceği işleri yapmış, gösterebileceği kadar fedakarlığı göstermiş ve son kuvveti son ümidi ile üzerimize yüklenmektedir. Biz imanını kuvvetinden, kuvvetini hakkından, hakkını tarihinden alan celadetli dillerimizle Allah'ın tekbirini söyleyerek ve kalplerimizde zaferin atışlarını taşıyarak düşmanla 
çarpışıyoruz. Beş altı gündür Yenişehir'den Afyonkarahisar'a kadar bir cephede harp yapıyoruz. Her dere bir ateş her tepe bir yanardă̆ oldu. Güllelerden, zelzelelerden, tayyarelerden yıldırımlar düşüyor. Bütün harp edilen yerler gürültülü dumanlı bir yangın sahasına döndü. Güneşin koynundan alınmış gibi yakıcı, arzın lavlarından kırılmış gibi lavlı bir yangın. Hepimiz nazarlarımızı bu yangına diktik. Hepimiz Yunanın attığı son koz olduğunu bildiğimiz bu harp ile meşgulüz. Her gün heyecanla gelen raporları soruyor, her dakika sabırsızlıkla kahraman ordumuzun vuracağı kat'i darbeyi bekliyoruz. Fakat bu dıştaki harpten başka içte de diğer bir harp var. Bir harp ki sel gibi akan kanlarl kulakları sağır eden gürültüleri yok. İhtimal bunun için çoğumuz bu ikinci harbin farkına bile varmadık. Her gün gazetelerde dıştaki harp raporlarının heyecanlı satırlarını okurken ihtimaldir ki evvelki gün bir telgraf çok kimsenin nazarına bile çarpmad. Halbuki o telgrafta diğer bir harpten bahsediliyordu. Çünkü o telgraf muallimler konferansının küşadını bildirmiştir. İhtimal o telgrafı sadece bir kongre küşadını bildiren bir haber ve bu hadiseyi sadece iki yüz muallimin bir araya toplanmasından ibaret ehemmiyetsiz bir vak'a zannettik. Kongre'yi bizzat Mustafa Kemal Paşa'nın açması, Kongre'de azaların her birinin elini ayrı ayrı sıkması ve Kongre'yi açarken parlak bir konuşma yapması belki de çoğumuza o büyük reisin maarife karşı sadece bir cümlesi gibi göründü. Halbuki Kongre'nin böyle bir zamanda öyle bir kişi tarafindan açılması onu sıradan bir kongre olmaktan çıkardı. Düşman bütün kuvvetiyle hayatımıza kast için taarruza kalkmışken bizim Ankara'da bütün muallimleri toplamış olmamız, hudutta bütün tarihimizin en önemli en hayati harbi cereyan ederken Paşa'nın muallimlere hitap etmesi, ötede kanlı bir savaş verilirken beride istikbali kurtarmak isteyen bir meclis kurulması takdir edilecek yüksek bir iştir.

Bu Kongre'de maarif hayatı için tamamen elverişli kararlar alınacak mı? Burada alınan kararlar bütün vatana tatbik edilebilecek mi? Tatbik edilen o kararlardan yeni bir hayat yeni bir irfan doğacak mı? Ben şimdiden buraları düşünüyorum bile. Benim şimdiden düşündüğüm Kongre'de yapılan müzakereler, o müzakerelerde verilecek kararlar, o kararlardan çıkacak neticeler değil. Benim şimdi düşündüğüm böyle bir zamanda böyle bir Kongre’nin açılmasından çıkacak manadır. Bir mana ki yalnız Türklerin bütün maarif hayatında ilk defa böyle bir kongre topladıklarını değil, yalnız hükümetin Millet Meclisi'nin maarife ne kadar ehemmiyet verdiğini değil, yalnız Anadolu kıyamındaki gayenin ne kadar nurlu olduğunu değil, bir mana ki Türklerin nefsine ne kadar itimadı olduğunu gösteriyor. Bir mana ki düşman taarruzu karşısında geleceğe ne kadar emniyetle baktığımızı gösteriyor. Bir mana ki cehaletle mücadelenin düşmanla çarpışmaktan hiç farkı olmadığını gösteriyor. Mustafa Kemal Paşa'nın Kongre’yi açmasından bir gün evvel gelen telgrafta yazan şu sözlere dikkat etmeliyiz: silahla olduğu kadar dimağla da mücadele mecburiyetinde olan milletimizin ikinci sahada da birinci sahada olduğu gibi zafer elde edeceğinden eminim. 
Anadolu'nun başında bulunan kişi ilan ediyor ki karanlığı yaran nur zaferi kazanan kılıçtan farklı değildir. Bu ilan hem de düşman taarruzu başladıktan üç dört gün sonra yapılmıştır. Düşman taarruzu başladıktan üç dört gün sonra Anadolu’nun başında bulunan zatı, muallimlerin de başında buluyoruz. O ellerindeki irfan meşaleleriyle cehaletin karanlıklarını parçalamak için toplanan muallimlere maarif sahasında dahi harpte olduğu gibi muzaffer olacă̆ımızı söylüyor. İşte düşman taarruzundan üç dört gün sonra söylenen o sözler, düşman taarruzundan üç dört gün sonra o toplanıştır ki maarif hayatımızın ilk ve en büyük zaferi oldu.

Umumi Harb’in Itilaf Devletlerine gülümsediği zamanlarda Ingilizler en büyük ümidi Almanların açlığından beklerken onların fevkalade teşkilatla bunun önüne geçtikleri bir devirde daha yeni başvekil olan Lloyd George dedi ki: Almanların kırk milimetrelik toplarından değil ekmeklerinden korkuyorum! Şimdi de aynı başvekil Ankara'daki muallimler konferansını nasıl haber aldıysa kaşlarını çatarak şunu söylenmiştir: Türklerin hiç yoktan ordular çıkarmasından değil, orduları kanlı bir harple uğraşırken onların böyle bir kongre açmalarından ürküyorum.

Kurulduğu günden itibaren Millî Mücadele'nin gür seslerinden olmayı başaran Hakimiyet-i Milliye gazetesinde de Açıksöz gazetesinde yayınlanan yazı kadar etkileyici bir yazı yer almıştır. "İki Cephe" başlığı altında yayınlanan yazıda gazetenin baş yazarlarından İsmail Hami Bey, felah ve istiklal ordusunun cephelerde Yunanlılar ile savaşırken muallim ordusunun da Ankara'da cehalete karşı savaş verdiğinden söz etmiştir (Hami, 1921: 1). Yazıda bu iki faaliyetin aynı anda gerçekleşiyor olması ulu bir tesadüf olarak nitelendirilmiştir:

Cephelerde felah ve istiklal ordusu Yunan ile mücadele ederken Ankara'da muallimler ordusu cehalete karşı müdafaa programını hazırlıyor. Harp ve maarif cephelerinin ikisinde de faaliyet var. Vatandan, milli ordu düşmanı; muallim ordusu da cehaleti ve zulmeti kovacak. İki faaliyetin aynı zamanda gerçekleşiyor olması ulu bir tesadüftür.

Anadolu hareket-i milliyesini vaktiyle adi bir isyan zanneden ve bu hareketin büyük ve muhterem reisine "asi general" diyen Avrupa ricali Ankara'da bir Muallimler Kongresi toplandı̆̆ını ögrendikleri zaman iki sene evvelki hükümlerinin hicabını bir kere daha duyacaklardır. Türk hareketi milliyesi isyan hareketi değildir. Zalimlere ve müstevlilere karşı tarihi bir milletin hak ve bekasını müdafaa eden asil bir hayatta kalma hareketidir. Bu hareket esaslarını yalnız müdafaa-i askeriyeden ibaret olarak görmemiştir. Milletin bekasına ait bütün endişelerle meşru ve medeni bir hamledir. Bugün ordu kadar mektebi, asker ve zabit kadar talebe ve muallimi de düşünen istiklal davasını istikbal kaygısıla beraber götüren genç bir hükümet doğmuştur. Cuma (14 Temmuz 1921) gecesi Erkan-l Harbiye'de güneşe kadar harbi takip eden hükümet reisi, dört saat sonra Daru'l-muallimin Salonunda 
Muallimler Kongresi'ni açmıştır. Ve Türk neslinin mürebbilerine irfan mücadelesinde gidecekleri yolu işaret etmiştir. Mustafa Kemal Paşa, üçüncü Yunan taarruzunun en ateşli zamanında muallim ordusunun müstakbel vazifesiyle meşgul bulunuyor. Bu necip ve ulu misal Türk tarihinin kıymetli hatıralarından birisi olacaktır.

Muallimler Kongresi, Ankara'daki iki haftalık içtimaında ne yapacak? Mustafa Kemal Paşa yapılacak işin en mühimini isabetle göstermiştir. Bu iş garptan gelen ecnebi fikir ve terbiye unsurlarından uzak bir program hazırlamaktır. Paşa milletin çocuklarının hudut ve gümrük tanımadan gelen ecnebi fikirlerinden azade bir irfan hamlesiyle yetiştirilmesi fikrindedir. Milli ordu hudutlardan gelen ecnebi istilasını defi' için nasıl çalışıyorsa muallimler ordusu da Türk çocuklarını saran ecnebi terbiye unsurlarına karşı cidal açmalıdır. Türk neslini kendi tarihinden, kendi mefahirinin, kendi terbiyesinin ilham ve irşadı ile yetiştirmelidir. Garptan ve şarktan maddi olarak alacağımız şey çoktur. Fakat garbın ve şarkın medeniyetimize aykırı unsurlarından alınmış bir şeyimiz olmamalıdır. Muallimler Kongre'si şu klsa içtima devresinde şüphe yok ki en çok bu esasın neticesine gayret edecek ve gelecek senelerin tedris ve terbiye programları bu maksada göre münakaşa edilecektir.

Cephelerde azgın ve kanlı muharebeler olurken bugün Ankara'da toplanan muallimler sükûn içinde milli irfan programını hazırlıyorlar. Yarın onlar da vazife başına dönecek, milli ordunun cepheleri kurtarmaya yönelik mücadelesini, cephe arkasında cehalete ve zulmete karşı açacakları cihad ile ikmal edeceklerdir. Irfan-ı milliyemizin hareket planlarını düş̈̈necek hakiki mütehassislardan mürekkeb böyle bir içtimaya büyük bir ihtiyaç vardı. Bu ihtiyacı has ederek hem istikbali hazırlamak hem de irfan ordusu ümera ve zabitanına birbirlerini tanımak firsatını veren böyle bir kongreyi topladığından dolayı Maarif Vekili muhteremini tebrike şayan buluruz.

Anadolu'da Yeni Gün gazetesi yazarlarından Cemal Hüsnü Bey ise "Düşmana ve Cehalete Karş1" başlıklı bir yazı kaleme alarak Kongre'nin kendisinde yarattığı etkiyi şu ifadelerle ortaya koymaya çalışmıştır (Hüsnü, 1921: 1):

Harp bütün şiddetiyle devam ediyor. Düşman hışmını artırıyor. Erkek, kadın, çocuk demiyor kesiyor. Mehmetçiğin kurşunu korkak düşmana haddini bildirdikçe geriye çekilen düşman her bastı̆̆ yeri kana boğuyor, harabeye çeviriyor. Bütün bu kanlar tarihin en yüksek ve en şerefli ordusu olan mukaddes Mehmetçiklerin kanıdır. Harabeye çevrilen memleketler, Türklerin bütün şeref ve medeniyetlerine asırlardır mukir (kabullenmiş) olan topraklardır. Namusun klymetinden habersiz olan düşman bastı̆̆ her yere mufahazatını beraberinde götürüyor. İstiklal aşkı intikam emeliyle ateş kesilen Mehmetçik düşmana haddini bildiriyor. Son zafer artık takarrüb etti. 
Maksatların en adisine duçar olan Türk milleti hudutlarında düşmanı kan deryasına boğarken arkada da harplerin en müthişine hazırlanıyor. Cehaletle mücadele için bütün kuvvetini seferber ediyor. Cuma günü inikad eden Muallime ve Muallimler Kongresi işte bu harbin Erkan-ı Harbiyesi'dir. Kan ve ateş mücadelesi yapan bir millet aynı zamanda neticeden emin büyük bir soğukkanlılıkla ilim cihadına da girişmiş, her iki cepheyi aynı şiddet ve azimetle müdafaa ediyor. Her iki düşmana da aynı şiddetle hücum ediyor. Bir elinde silahı diğer elinde ilim meşalesi istiklali, istikbali müdafaa ediyor. Bu kadar yüksek anlar yaşamak hiçbir millete nasip olmamıştır. Büyüklükten başka şeyi ihtiva etmeyen Türk tarihine aynı derecede bir büyüklük daha ilave edildi.

Hiç şüphesiz cuma günü açılan Muallime ve Muallimler Kongresi Türk siyasi tarihiyle medeniyet tarihinde pek büyük bir safhasının bidayetini teşkil eder. Bu mühim hadisenin haiz olduğu himmeti bu yüksek millet hakklyla takrir etmiş ve bu tamamen meşru bir hareket olmuştur. Bunun içindir ki muhterem milletimizin aziz mümessillerinin azimkar reisi irfan tarihimizde yegâne ve müstesna olan bir nutuk ile Kongre'yi bizzat açmış, Kongre'nin mahiyeti itibarı ile ne kadar büyük neticeler beklediğini en beliğ bir surette izah etmiştir. Yalnız bu hadise bile Türk milletinin istiklal ve medeniyete olan kabiliyetini bugüne kadar görmeyen ve görmek istemeyen gözlere en kati bir delildir. Büyük Millet Meclisi Reisi hazretleri Kongre’ye iştirak eden muallime ve muallimlerle birer birer musafaha (selamlaşmak) ederek kendilerine teşekkür etmiş; bu ilim irfan kongresine milletin verdiği ehemmiyeti bütün güzelliği ile arz eden en canlı bir manzara ortaya koymuştur. İlim ve irfan tevciye (sunulan) edilen bu Kongre artık gerçek bir ilim maarifinin başladığını ilan eden tarihi bir kongredir.

İşte Muallime ve Muallimler Kongresi bu kan ve ateş kokusu içinde toplanıyor. Elinde silahı ile hududumuzda istiklal mücadelesi veren memleketin aziz ve azimkar bekçileri diyor ki: Bugün kazandığımız istiklali siz de ilim irfan sahasındaki muzafferiyetinizle temin ve idame edeceksiniz. Şehitlerimiz düşmanı yere vurmak için kanlarını hiç esirgemediler. Azim ve imanınız elbette bizimki ile boy ölçüşmelidir. Yine o elleri, büyük millet namına sıkılan muallimlere diyor ki: Hakiki halk saltanatı sizin azminiz sayesinde temin edilecektir. Biliniz ki Muallimler Kongresi bu yüksek ve tarihi vazifesi, eski Türk harikalarından özünü almış şarktan ve garptan gelen ecnebi tesirlerden uzak ve milli unsurlarımız ile mütenasip bir kültürün esasını kuracak kararlar almakla başa çıkacaktır. Ulu tanrı Yüce Türkü her sahada muzaffer etsin.

20 Temmuz 1921 tarihli Anadolu' da Yeni Gün gazetesinde ise “Muallimler Ordusu” başlığı ile kaleme alınan köşe yazısında öğretmenler için “Türklüğün hak ve hürriyetini kahramanca müdafaa eden harp ordumuz kadar Türklüğ̈̈n benliğini öğretecek nesli hazırlayan, düşmanın başka bir kuvveti olan cehalet ile savaşan ilim ve irfan silahını teçhiz ve tam manasıyla kuşanan muallim ordusunun Erkanı Harbi muallimlerdir.” sözü kullanılmıştır. Yazının devamında Maarif Kongresi ile ilgili olarak ise 
şu sözlere yer verilmiştir: “Kongre ulu Türkiye’nin ve Türklüğün yeni bir hayat irfanına muhtaç olduğuna bir gösterge teşkil ediyor. Kahraman ordumuz sayesinde mevcudiyetimizi, hukukumuzu nasıl evvel Allah koruyacă̆ımıza şüphe yoksa Türklüğün mevcudiyetinin müdafaasında da Türk milletinin düşmanı olan cehaleti de yok edeceğimize şüphe yoktur. Milli Hükümet'e içinde bulunulan şartlar ne olursa olsun muallim ordusunun temelini tesisi için Kongre'yi ihdas eylemesinden dolayı ne kadar takdir ve teşekkür edilse azdır."

Yukarıda bahsettiğimiz haberin detaylarında ise muallim ordusu yetiştirmek için Meşrutiyet'in ilanından sonra defalarca teşebbüste bulunulduğundan fakat gerek konunun öneminin tam kavranamamasından gerekse harp koşulları nedeniyle bu teşebbüslerin başarıya ulaşamadığından bahsedilmiştir. Devamında ise milli hükümetin kurulması ile eğitim konusuna verilen önemin arttığı ve cehaletin de en az Yunan kadar tehlikeli bir düşman olduğunun fark edildiği ifade edilmiştir (Anadolu'da Yeni Gün, 1921: 1).

Bütün bunların yanı sıra gerek gazetelerde yer alan haberlerden gerekse köşe yazılarından Kongre'de öğretmenlere ayrı bir önem verildiği anlaşılmaktadır. Nitekim Kongre’nin açılış konuşmasını yapan Mustafa Kemal Paşa konuşmasında öğretmenleri, "Gelecekteki kurtuluşumuzun öncüleri” olarak nitelemiştir (Akyüz, 2008: 320-323). Gazetelerde yer alan hemen her yazıda memleketin geleceğinin öğretmenler sayesinde aydınlanacağına, öğretmenlerin cephede savaşan silahlı ordu kadar mühim görevleri olan muallim ordusu olduğuna vurgu yapılmıştır. Anadolu'da Yeni Gün gazetesi yaptı̆̆ı bir haberlerde gelecek nesli inşa edecek terbiye programı kadar bu programı uygulayacak öğretmenlerin de yetiştirilmesinin öneminden ve bir eğitim ordusunun göreve hazır hale getirilmesinin gerektiğinden bahsetmiştir. Öğretmenlerin vazifelerini yerine getirirken son derece aşk sahibi olması gerektiğinin belirtildiği haberde "Öyle bir aşk ki senelerin değil asırların ve başka cananların arz-ı endam etmeleri ile bozulmaya yüz tutmasın." ifadesi kullanılmıştır. Devamında ise Kongre'de alınacak kararlar doğrultusunda öğretmenlerin sadece Türkiye Türkleri için değil dünyanın dört bir tarafındaki Türklerin istiklali için çalışacağını belirten şu sözlere yer verilmiştir: “O muallim ordusu ki yalnız muhiti olan şimal Türklerini değil Türk'ün birleşmesine mani için Çarlık hükümeti tarafindan istiklal hakkından bile mani edilmiş olan Kırgızistan'dan Türkistan'a kadar her taraftan mektepler yapmış bir derin gaflet uykusunda olan bu muazzam Türk milletlerine hayat-ı irfan ve siyaset yolu göstermektedir." (Anadolu'da Yeni Gün, 1921: 1). Anadolu'da Yeni Gün gazetesinin başka bir nüshasında ise öğretmenler hakkında "Muhtelif meslekler arasında mükafat-ı maddiyesi hemen hiç olan muallimlik kadar sabır ve sebata muhtaç bir meslek yoktur." ifadesi kullanılmıştır (Anadolu’da Yeni Gün, 1921: 1). Hakimiyet-i Milliye gazetesinde yer alan şu ifadeler ise öğretmenlerimizin ve öğretmenlik mesleğinin kutsiyetini bundan tam yüz yıl öncesinin ifadeleri ile net bir biçimde özetlemektedir: 
“Arkası kesilmeyen harplerin ortasında babasız kalan yüz binlerce şehit çocuklarının babaları herkesten evvel muallimlerdir. Bu çocukları harama el uzatmayacak bir terbiye ile yetiştirmek, onları hayat ortasında kendi ellerinin emeği ile kendi ekmeklerini kazanabilecek kabiliyete mazhar kllmak öğretmenlerin vazifelerinin esasını teşkil etmektedir.” (Hakimiyet-i Milliye, 1921: 1).

\section{SONUÇ}

Tarihleri boyunca eğitime büyük önem vermiş Türkler, düşmanlarına karşı vatanlarını savunmak üzere giriştikleri Millî Mücadele döneminde de eğitim konusunu en ön planda tutmuştur. Öyle ki Anadolu'da üçüncü Yunan taarruzunun başladığı sırada Ankara'da toplanan bu Kongre yurdun farklı yerlerinden 250'den fazla öğretmeni bir araya getirmiştir. Mustafa Kemal Paşa da bizzat cepheden gelerek Kongre'nin açılışını gerçekleştirmiştir. Paşa, yaptığı açılış konuşasında Kongre’yi “Dünya tarihinde bir benzeri daha olmayan örnek durum. ” olarak nitelemiş; öğretmenlerin üçüncü Yunan taarruzunun başladığı bir dönemde gelecek vazifesi ile ilgilenmesini ise "Türk tarihinin ender görülen klymetli hatıralarından biri. ” olarak göstermiştir.

1921 Maarif Kongresi'ni sadece eğitim ile ilişkilendirmek de yetersiz kalacaktır. Çünkü Kongre’nin toplanması ile dönemin askeri havası da yumuşamıştır. Gazetelerde sürekli cephelerden gelen haberlerin ve bu haberler üzerine yazılan köşe yazılarının yerini Kongre'nin önemini anlatan, okuyana geleceğe dair umut aşılayan haberler ve köşe yazıları almıştır. Bu yazılar sayesinde halkın zafere olan inancı artmış ve bütün vatanda taze bir umut havası esmeye başlamıştır. Anadolu basını Millî Mücadele boyunca olduğu gibi bu Kongre sırasında da üzerine düşen görevi yapmış ve vatanın geleceği için mücadele eden kadrolar ile halkı ortak bir düşüncede buluşturmayı başarmıştır.

Maarif Kongresi, devam eden savaş şartları nedeniyle çalışmalarını uzun bir zaman dilimine yayamamıştır. Nitekim Kongre boyunca tartışılan ilk ve ortaöğretim programları, köy öğretmeni yetiştirilmesi vb. konular hakkında kesin bir karar alınamamıştır. Fakat Kongre toplanış zamanı olarak oldukça yüksek ses getirmiştir. Savaş yıllarında eğitim işlerinin görüşülmesi ve eğitimde yapılacak yeniliklerin tartışılmış olması dahi geleceğe dair atılmış büyük bir adım olarak görülmüştür. Eğitim konusundaki eksiklerin belirlenmesi, modern öğretmenlerin yetiştirilmesi, çağdaş eğitimin gereklilikleri vb. konular Kongre'de bir hafta boyunca tartışılmış ve daha sonra yapılacak yeniliklere bir temel oluşturulmuştur. 


\section{KAYNAKÇA}

Akyüz, Y. (2004). Türk Eğitim Tarihi (M.Ö. 1000-M.S. 2004), Pegem Akademi Yayınc1lı, Ankara.

Alp, H. (2020). “Milli Mücadele’nin Çetin Şartlarında Maarif Müdürü Osman Nuri (Oral) Bey'in Gözünden Türk Eğitimine Bakış (1922-1923)", History Studies, 4(12), 1393-1417.

Armoğlu, F. (1993). 20'nci Yüzyıl Siyasi Tarihi (1914-1990), Türkiye İş Bankası Yayınları, Ankara.

Atatürk, M. K. (1970). Nutuk, 2. Cilt, Milli Eğitim Basımevi, İstanbul.

Coşar, Ö. S. (1964). Milli Mücadele Basını, Gazeteciler Cemiyeti Yayınları, İstanbul.

Erat, M. (2016). Milli Mücadele Tarihi, Paradigma Yayınları, Çanakkale.

Erat, M. (2013). Türkiye Cumhuriyeti Tarihi (Ed: M. Erat), Kriter Yayınevi, İstanbul.

Gezgin, S. (2007). Türkiye'de Yerel Basın, İstanbul Üniversitesi İletişim Fakültesi Yayınları, İstanbul.

Göldaş, İ. (1981). Milli Kurtuluş Savaşı'nda Öğretmenler, Öğretmenler Dünyası Yayınları, Ankara.

Gündüz, A. (1973). Hatıralarım (Der: İ. Ilgar), Kervan Yayıncılık, İstanbul.

Habip, İ. (1921). “İçteki Harp”, Açıksöz, 20 Temmuz.

Hami, İ. (1921). “İki Cephe”, Hakimiyet-i Milliye, 18 Temmuz.

Hüsnü, C. (1921). “Düşmana ve Cehalete Karşı”, Anadolu'da Yeni Gün, 18 Temmuz.

Karakütük, H. (2021). Türk Basınında Sakarya Meydan Muharebesi (Temmuz - Ekim 1921). (Yayınlanmamış Yüksek Lisans Tezi). Çanakkale Onsekiz Mart Üniversitesi.

Koloğlu, O. (1994). Osmanlı'dan Günümüze Türkiye'de Basın, İletişim Yayınları, İstanbul.

Koloğlu, O. (2014a). İlk Gazete İlk Polemik, Kaynak Yayınları, İstanbul.

Koloğlu, O. (2014b). Hainname, Tarihçi Kitabevi, İstanbul.

Özcan, A. (2011). Türkiye'de Popüler Tarihçilik (1908-1960), Türk Tarih Kurumu Basımevi, Ankara.

Öztoprak, İ. (2014). Türk ve Batı Kamuoyunda Milli Mücadele, Türk Tarih Kurumu Yayınları, Ankara.

Rencüzoğulları, S. (2017). “İslamiyet Öncesi Dönemde Türklerde Eğitim”, 21. Yüzyılda 
Eğitim ve Toplum Eğitim Bilimleri ve Sosyal Araştırmalar Dergisi, 6(17), 425-437.

Kılavuz, N. ve Tanık, İ.H. "Millî Mücadele Döneminde Maarif Kongresi ve 1. Türkiye Büyük Millet Meclisi’nin Eğitim Öğretim Hakkındaki Görüşleri”, Erzincan Üniversitesi Sosyal Bilimler Enstitüsü Dergisi, 4(2), 353-379.

Sarıhan, Z. (2019). 1921 Maarif Kongresi, Tarihçi Kitapevi, İstanbul.

Sonyel, S. R. (2003). Türk Kurtuluş Savaşı ve Dış Politika. 1. Cilt, Türk Tarih Kurumu Yayınları, Ankara.

Yılmaz, H. (2014). Peyam-1 Sabah Gazetesinde Millı̂ Mücadele. (Yayınlanmamış Doktora Tezi). Marmara Üniversitesi.

Zekai, G. (1999). Milli Mücadele Başlarken Türk Kamuoyu, Kalkan Matbaası, Ankara.

(1921). “Ankara’da Müsamereler”, Vakit, 14 Temmuz.

(1921). “Evvelki Gün Maarif Kongresi Açıldı”, Hakimiyet-i Milliye, 17 Temmuz.

(1921). "Halk Mektepleri”, Vakit, 20 Temmuz.

(1921). “Halk Mektepleri”, Hakimiyet-i Milliye, 21 Temmuz.

(1921). "Maarif Bütçesine Tahsisat İlavesi”, Tevhid-i Efkar, 15 Temmuz.

(1921). "Maarif Bütçesine Zam”, Tercüman-1 Hakikat, 14 Temmuz.

(1921). “Maarif Kongresi”, Anadolu'da Yeni Gün, 18 Temmuz.

(1921). "Maarif Kongresi”, Anadolu'da Yeni Gün, 20 Temmuz.

(1921). “Maarif Kongresi”, Anadolu'da Yeni Gün, 21 Temmuz.

(1921). "Maarif Kongresi”, Hakimiyet-i Milliye, 31 Mayıs.

(1921). “Maarif Kongresi”, Hakimiyet-i Milliye, 3 Haziran.

(1921). “Maarif Kongresi”, Hakimiyet-i Milliye, 13 Temmuz.

(1921). “Maarif Kongresi”, Hakimiyet-i Milliye, 14 Temmuz.

(1921). “Maarif Kongresi”, Hakimiyet-i Milliye, 18 Temmuz.

(1921). “Maarif Kongresi”, Hakimiyet-i Milliye, 22 Temmuz.

(1921). “Maarif Kongresi'nde Yeni Tedrisat-1 İptidaiye Programı”, Anadolu'da Yeni Gün, 17 Temmuz. 
(1921). “Muallime ve Muallimler Konferansı”, Açıksöz, 17 Temmuz.

(1921). “Muallime ve Muallimler Konferansı”, Hakimiyet-i Milliye, 20 Temmuz.

(1921). “Muallimler Konferansı Açıldı”, Anadolu'da Yeni Gün, 17 Temmuz.

(1921). “Muallimler Konferansı Açıldı” Anadolu'da Yeni Gün, 18 Temmuz.

(1921). “Pek Veciz Bir Nutuk”, Açıksöz, 26 Temmuz.

(1921). "Pek Veciz Bir Nutuk”, Hakimiyet-i Milliye, 21 Temmuz.

(1921). "Yeni Devir ve Türkiye”, Anadolu'da Yeni Gün, 15 Temmuz.

\section{Education Congress In The Turkish Press EXTENDED SUMMARY}

Through the first World War, the Ottoman Empire had to fight on many fronts simultaneously. At the end of this war, he suffered from a heavy defeat. After the war, as a consequence of the Armistice of Mudros, Ottoman Empire was occupied by the Entente States. The inability of the Ottoman government to find a way of salvation against the occupation of its territory led the Turkish nation to mobilize to save its independence and Homeland. The National War of Independence began with the organization of the Turkish nation against the invaders around the people elected as its leader. After completing the organization process at the congresses of Erzurum and Sivas, The National independence achieved military successes against the Armenians in the East and against the Greeks in the first and Second İnönü War in the West with the opening of the Parliament. In the KütahyaEskişehir battles, the army was forced to retreat to the Western banks of the Sakarya river, but with the victory of the Battle of Sakarya, a great success was achieved in defending the homeland. A year after this victory, with the great offensive movement, all the invaders in the Turkish homeland, especially the Greeks, were expelled from the country.

Another important issue to be solved during the First World War and Turkish War of Independence was Education. The long years of war and the economic and political collapse of the Ottoman Empire in recent times came out in the field of education as well as in all areas. For this reason, the newly established Turkish state, as briefly mentioned above, was in a Total War and had to fight ignorance at the same time. Education is the most important factor in maintaining the characteristic of a nation. At the same time, the education guarantees the future and existence of a nation. For this reason, an education congress was organized during the hardest times of the national independence. This clearly shows that it is as important to fight the enemy at the front as to fight the ignorance within the country. 
As we have seen in the newspapers that we examined throughout the study, at that time the war with ignorance was seen as a second front separate from the war with the enemy, and therefore it was decided to convene an education Congress.

The main question we focused on this study was how the society reacted to this congress via the news and columns in the press during the war. Because most of these newspapers that continued to broadcast in this period were prepared by people from the public. These people were among the people and when necessary, organized the people in the ranks of the national independence, and went to the front line and fought. For this reason, those are the people who will convey the thoughts of the society clearly. It is seen throughout the study that the Turkish people supported the leaders of the national independence in this second front against ignorance during the war.

When we give an eye on Turkish history, we see that the first modernization movements in the field of education started in the Tanzimat period. Although many steps were taken in this regard during the Ottoman Empire, the desired level of modern education could not be reached. In particular, the collapse of the state in many areas in recent years has caused the issue of education to remain in the background. With the proclamation of the new Turkish state, real modern steps began to be taken in this regard, and the first of these steps was the 1921 Education Congress. For this reason, this Congress needs to be addressed in many dimensions. The main feature of the study that distinguishes it from other studies on the subject is that press and publication tools were used as the main source and the study was based on the data obtained from these sources.

The study named as "1921 Education Congress in The Turkish Press" is basically based on the news and columns published in the newspapers of the period. The news about this congress in newspapers and magazines were supported by various primary and secondary sources, especially the memories of eyewitnesses of the period, to create a whole. In addition to these, different sources such as symposiums, conferences, archives, digital archives, as well as thesis, articles and papers published on the subject were used in the process of creating the study. These resources are located; "Beyazit State Library, Istanbul University Rare Works Library, Istanbul Metropolitan Municipality Taksim Atatürk Library, Karadeniz Technical University Faik Ahmet Barutçu Library; Bonn University Digital Archive Database, Hakkı Tarı Us Collection, National Library Digital Archive, Ankara University Faculty of Political Sciences Digital Archive etc.". The Ottoman resources obtained from the aforementioned libraries or databases were primarily transcribed into Latin letters, which are used to express the Turkish language today. The information obtained after this process was made ready to be brought to the study area by going through the stages of analysis, synthesis and evaluation in line with historical methods. 
As we mentioned before, this congress was held in a time that is important for the Turks. The congress exactly coincides with the period when the Greeks started a new attack on the Kütahya-Eskişehir line. So that when the congress started, the Greek army captured Kütahya and Afyonkarahisar and came to the front of Eskişehir. During the congress, when the Turkish army maneuvered to withdraw to the east of the Sakarya river, Eskişehir the ancient city of Turkey, which was hundreds of years old, was captured by the Greeks. In those days, some volunteer deputies even started to go to the front.

The first news that the Congress would convene were in the Hakimiyet-i Milliye newspaper, dated May 31, 1921. According to the news of the newspaper titled as Education Congress, an education congress will be held in Ankara between 15-21 July 1921 with the initiatives of Mustafa Kemal Pasha. In the content of the news, it was stated that all of the centers close to Ankara and three or four of the centers that are far away will attend the congress. Accordingly, each center's education director, teacher's school principal and high school (sultani) principals; In places where there is no teacher school, the secondary school inspector will come to the congress. The topics to be discussed in general at the congress are as follows: The number of teachers and their distribution according to the population, the number of schools in the country and the grades of the schools, school buildings, the grades of the teachers, the number of students and the grades of the students, the work done by the parents of the students, the amount and grades of the girls' schools.

Hakimiyet-i Milliye newspaper broke news on the subject on different days throughout July and shared the details. In this process, newspapers such as Vakit, Açıksöz, Anadolu'da Yeni Gün, Tevhid-i Efkar, Tercüman-1 Perakende showed great interest in the subject and conveyed almost identical news to their readers.

Thru the period of the congress, the interest of the newspapers on the subject continued and various news related to the subject took place in the newspapers. Aç1ksöz newspaper in the news with the title of Teachers Conference in its issue dated July 17, 1921 reported that two hundred members from all over Anatolia participated in the congress, which was opened with the speech of Mustafa Kemal Pasha. According to the details of the news, Mustafa Kemal Pasha, who presided over the congress, shook the hands of the participants one by one. In his speech at the conference, Mustafa Kemal Pasha stated that the scientific development is as important as the armed struggle for the future of the homeland. In his speech, Pasha stated that the nation was fighting on two fronts, both in the military field and the scientific field, and stated that they would be victorious in both fields. This speech was strongly applauded by the participants. In its news dated July 17, 1921, Hakimiyet-i Milliye newspaper conveyed to readers that the Educational Congress was opened on Friday, July 15, at the Darülmuallimin Conference Hall, by the President of the Grand National Assembly, Mustafa Kemal 
Pasha, with the title "The Day Before the Educational Congress Opened". Stating that there were nearly one hundred and eighty members who came from various parts of Turkey and gathered in Ankara at the congress, the newspaper reports that both the congress hall and the surrounding buildings are equipped with flags and signs. According to the newspaper, Mustafa Kemal Pasha arrived at the congress hall at three o'clock in the afternoon. Members of the congress were presented one by one to His Excellency Mustafa Kemal Pasha by Deputy Education Minister Hamdullah Suphi Bey. After this presentation ceremony, an important and very valuable speech was made by Mustafa Kemal Pasha. After this important speech, which was met with enthusiastic applause, Sivas Education Director Osman Nuri Bey with a reply thanked on behalf of the teachers who participated in the congress. After this speech came to an end, a letter was read out, expressing the satisfaction felt for the congress, sent by the General Presidency of the Teachers' Association, which is concluding its annual congress in Istanbul.

An editorial on the subject was published in the Hakimiyet-i Milliye newspaper, published on July 18, with the title "İki Cephe", written by İsmail Hakkı Bey, one of the editorial writers. When we look at the article in general it is mentioned that we see the Turkish army was fighting with the invading enemy on the front line for the safety of the homeland while the teacher's army was fighting with the enemy of ignorance inside the homeland. In addition, the content of the article also included that the western states, who thought that the national independence that started in Anatolia with this congress was primarily a rebellion, could no longer make such an accusation against our struggle in Anatolia. With this congress it is shown to the world that there is a nation believes in future and ensures its victory which its reborn is programmed. On the other hand, Açısöz newspaper published a detailed column on this subject in its 20 July 1921 issue with the article titled "Inner Warfare" by the editor-in-chief İsmail Habip. In the article, it was mentioned that while an armed struggle was waged with the enemy on the front, a war also was waged against ignorance in the homeland.

During the congress, the above-mentioned issues were discussed in general. In addition, the subjects of public schools and vocational education are among the subjects that are mainly discussed. The interest of the newspapers on the subject continued throughout the congress. Anadolu'da Yeni Gün newspaper, dated 21 July 1921, stated in its news titled Maarif Congress yesterday (July 20, 1921) at 12.00 that the congress held its fourth and last meeting under the presidency of Deputy Education Minister Hamdullah Suphi. Stating that some of the decisions taken earlier in the last meeting were reconsidered, the newspaper reported that the congress ended with the closing speech of the chief Hamdullah Suphi Bey at two o'clock in the afternoon. 